\title{
Sustainability of Thematic Kampongs
}

\author{
Surjono $^{1 *}$, Feronikana D.P. Rahma ${ }^{2}$, Deni A. Setyono ${ }^{3}$ \\ ${ }^{1,2,3}$ Departement of Urban and Regional Planning, Universitas Brawijaya, Malang, Indonesia \\ *Corresponding author. Email: surjono@ub.ac.id
}

\begin{abstract}
Indonesian urban areas are formed by the formal and informal pattern of settlement. Kampongs are a typical feature in the urban settlement, which are often misled as slum areas; therefore, it is important to see whether kampongs are sustainable or not. The research selects four thematic kampongs based on four dimensions to measure kampong's sustainable Multidimensional scaling (MDS) was used to measure the sustainability by incorporating four dimensions: economy, environment, social, and education. The result shows that the four kampongs were highly sustainable in economy, social, and education. The environment dimension was generally lower than the other three dimensions. The performance of each thematic kampong did not correspond with the theme.
\end{abstract}

Keywords: Settlement, multidimensional scaling, sustainability, thematic kampong

\section{INTRODUCTION}

The current sustainable development agenda addresses 17 goals, and the most relevant goal to the topic of this paper is to "make cities inclusive, safe, resilient, and sustainable" (goal 11). The notion of sustainable development is significant for all institutions to close the gap between the existing ones and the target of SDGs. Inspired by City Without Slums Action Plan developed by City Alliance and launched by Nelson Mandela in 1999[1], the Ministry of Public Works and Public Housing has also set a program called 'City Without Slums' (KOTAKU). This program was intended to support the 100-0-100 program (100\% access for drinking water, $0 \%$ slum, $100 \%$ access for adequate sanitation) [2], which is also very relevant to SDGs.

The important part of Indonesian cities is urban kampong [3]. Kampong is an urban settlement that used to be seen as an urban slum, e.g., by Hutama and Kristiadi [4] and Sudarwanto et al. [5]; however, kampong is also a settlement with strong social bonding that can generate a creative resource for self-help upgrading of the settlement. Creative kampongs are also the main parts of the creative city [6]. In Indonesia, Malang City is one of 30 cities that focus on integrating infrastructure development for slum upgrading. Creative kampong program is significantly supporting slum upgrading in many areas of the city [7].

Based on the spatial planning document for Malang City 2010 - 2030 and settlement and public housing planning document for Malang City 2012-2032, urban settlements and slum areas in Malang are delineated. Urban settlements in Malang City cover about 4,500 hectares that consist of regular kampongs $(87 \%)$, irregular kampongs $(1 \%)$, and housing estates $(12 \%)$. The irregular kampongs are also recognized as slums $\left(3^{\text {rd }}\right.$ Mid-Term Development Plan for Malang City 2013-2018). It shows that kampong is not always slum, and the potentials within the kampong community can be initiated to promote and develop creative ideas.

Malang Design Festival launched Thematic Kampong Competition in 2016 to select the creativity of local communities in improving their kampongs with unique themes. This competition was inspired by the 'successful' of community in Jodipan Kampong, supported by a corporate social responsibility (CSR) program of a local paint company, to create a colorful settlements landscape that generated local tourism [8]. However, the performance of these thematic kampongs needs to be evaluated to see the impacts of the program on the level of sustainability.

Since 2017 The Local Government of Malang City had evaluated the performance of Thematic Kampongs. The evaluation showed that those thematic kampongs could be distinguished into kampongs that have found their themes with good performance and kampongs that failed in sustaining their themes and unable to improve the performance. Initially, Malang City had 60 thematic kampongs, but some of them cannot sustain their themes (creativity). This paper, therefore, is aimed to assess the sustainability level of selected thematic kampongs. Our initial observation found four kampongs that were unique: Bibit, Pelangi, Terapi, and Sinau Kwansan Kampongs. These names are based on the themes of these kampongs. The themes are relevant to sustainable indicators. Bibit Kampong is based on the environment, while Pelangi Kampong, Terapi Kampong, and Sinau Kwansan Kampong are based on economy, social, and education, respectively.

\section{SUSTAINABILITY VARIABLES}

It has been already widely accepted that sustainable development consists of three dimensions: economic, social, and environment. While the sustainability of settlement, as Golubchikov \& Badyina proposed [9], 
comprises of four variables: economy, social, environment, and education. Other authors, Basiago [10] and Ibrahim et al. [11], have similar views related to these variables. These variables, based on recent authors' views, are broken down into sub-variables (Table 1).

Table 1 Sustainability variables

\begin{tabular}{|c|c|c|}
\hline Variables & Sub- Variables & Sources \\
\hline Economy & $\begin{array}{l}\text { Access to work; road network; } \\
\text { poverty level; income; } \\
\text { unemployment; energy power; clean } \\
\text { water (availability and quality); } \\
\text { telecommunication network }\end{array}$ & \multirow{4}{*}{$\begin{array}{l}\text { Lynch et.al; } \\
\text { Hidajat; } \\
\text { Chaidir, BPS } \\
\text { [12]; UN } \\
\text { Habitat [13]; } \\
\text { Science for } \\
\text { Environment } \\
\text { Policy [14]; } \\
\text { UN }\end{array}$} \\
\hline Environment & $\begin{array}{l}\text { Pepple density; cleanliness of the } \\
\text { environment; green open space; } \\
\text { clean water; drainage; recycle; } \\
\text { concern for the environment; waste } \\
\text { management }\end{array}$ & \\
\hline Social & $\begin{array}{l}\text { Security; health facilities; the } \\
\text { number of people who smoke; social } \\
\text { interaction; community } \\
\text { empowerment; the level of } \\
\text { community participation }\end{array}$ & \\
\hline Education & $\begin{array}{l}\text { Education quality; access to } \\
\text { education facilities; community } \\
\text { empowerment; the proportion of } \\
\text { guru/educators; access to the } \\
\text { internet; availability of education } \\
\text { facilities }\end{array}$ & \\
\hline
\end{tabular}

\section{STUDY AREA}

The study areas are distributed in three districts of Malang Cit (Malang has five districts). The size of each kampong is at 4th level (RW) of municipality administration of a city in Indonesia. In Indonesia, the administration of a city is divided into kecamatan (district), kelurahan (subdistricts), RW (neighbourhood) and lastly RT (subneighbourhood). Bibit Kampong is located at RW 3 of Kelurahan Lowokwaru, District of Lowokwaru (Fig.1). Pelangi Kampung is at RW 9 in Kelurahan Merjosari, Kecamatan Lowokaru. Terapi Kampong is at RW 3, Kelurahan Sukun, Kecamatan Sukun, while Sinau Kwansan Kampong is at RW 6, Kelurahan Sawojajar, Kecamatan Kedungkandang.

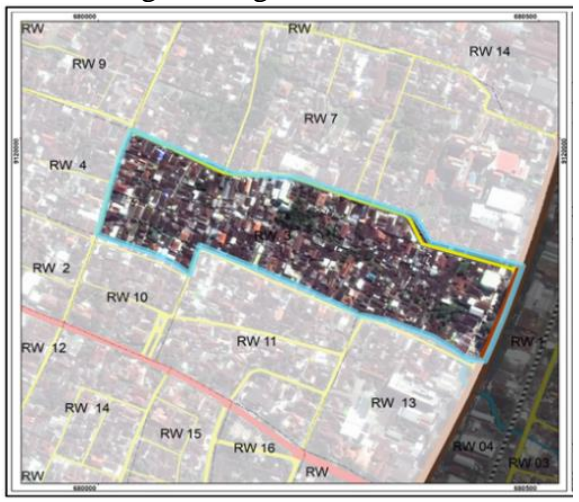

Figure 1 Bibit Kampong in the sub-district of Lowokwaru

\section{METHODS}

The methods in collecting and analyzing data are focused on answering two research objectives: 1) the condition of the four kampongs from four perspectives: economy, environment, social, and education. 2) sustainability level based on each concept.

\subsection{Data Collection Methods}

First, field observation and survey with an interview was conducted to obtain primary and secondary information needed to explore the condition for the four variables examined in this research. The economy variable comprises s of 9 sub-variables. The environment variable comprises of 8 sub-variables, while both social and education variables have 7 sub-variables each (Table 1).

Second, data for sustainability assessment were taken from questioners distributed to samples of the local community. The number of samples (301 respondents) were determined by Isaac and Michael's formula:

$\mathrm{S}=\frac{\lambda^{2} \cdot \mathrm{N} \cdot \mathrm{P} \cdot \mathrm{Q}}{d^{2}(\mathrm{~N}-1)+\mathrm{X}^{2} \cdot \mathrm{P} \cdot \mathrm{Q}}$, where

$\mathrm{S} \quad=$ number of samples

$\lambda^{2}=$ Chi square $5 \%=3.841$

$\mathrm{N} \quad=$ number of populations

$\mathrm{P} \quad=$ true probability $(0.5)$

$\mathrm{Q} \quad=$ false probability $(0.5)$

$\mathrm{d}=$ differences between sample average and population average 0.05

The distribution of samples in each kampong was determined from the proportion of the population of each kampung. The numbers of samples in each kampong are 72; 64;80; 85 samples for Terapi, Bibit, Pelangi, and Sinau Kwansan, respectively.

\subsection{Analysis Methods}

The analysis of the sustainability level of the thematic kampongs used multidimensional scaling (MDS) incorporating economy, social, environment, and health variables. Each sub-variable was assessed using the ordinal scale from 0 to 4 . The MDS used in this research adopted an application called Rapid Appraisal for Fisheries (Rapfish). The output Rapfish were indices at scale $0-100 \%$. The advantage of Rapfish is its ability to combine diverse aspects to be evaluated, and it provides the effect of the variables on the sustainability of the settlement. Several requirements of the MDS are: stress value should be less than 0.25 , and the R 2 must close to 1 , which means the number of attributes is accurate enough. The output of Rapfish indicates the sustainability status that can be categorized into four groups from unsustainable to very sustainable (Table 2). 
Table 2 Sustainability category status

\begin{tabular}{|c|c|}
\hline Index value & Category \\
\hline $0.00-24.99$ & Unsustainable \\
\hline $25.00-49.99$ & Less sustainable \\
\hline $50.00-74.99$ & Sustainable \\
\hline $75.00-100$ & highly sustainable \\
\hline
\end{tabular}

Source: Chaidir and Murtini [15]

Leverage analysis indicates sensitive attributes to the increase or decrease of the sustainability status. The determination of leverage attributes was based on the order of percentage changes of root mean square (RMS). The higher the RMS change value, the stronger the attributes to leverage sustainability status [16].

Monte Carlo analysis was conducted at a 95\% degree of confidence. This analysis was used to predict random error in the statistic process. The output of Monte Carlo analysis was compared with MDS to see the effect of determination error [16]

\section{RESULTS AND DISCUSSION}

The sustainability of the kampongs was evaluated using multidimensional scaling (MDS). The assessment was limited to four variables: economy, environment, social, and education. The elaboration of each aspect of subvariables is shown in Table 1.

\subsection{Economic Variable}

The sustainability of the four kampongs of the economic variable is shown in Table 3. The highest economic index is shown by Pelangi Kampong, while the lowest is Terapi Kampong. Pelangi Kampong was named pelangi because of its diversity of ethnics who live in this kampong. The characters of the economic variable can be described as follows. Most of the people in Pelangi Kampong work in private sectors with additional part-time jobs. Motorbike is the most common transport mode, while public transport, i.e., minibus, was not very popular. The condition of the road network in the four kampongs was relatively good; the damaged road was only found in some segments in Pelangi Kampong. Electricity power supply for the kampongs was distributed evenly. There was also no significant gap between the four kampongs for other infrastructure provisions (clean water and telecommunication)

Table 3 Economic sustainability variables

\begin{tabular}{|l|c|l|l|}
\hline \multicolumn{1}{|c|}{ Kampong } & $\begin{array}{c}\text { Sustainability } \\
\text { index }\end{array}$ & Stress & $\mathbf{r}^{\mathbf{2}}$ \\
\hline Bibit & 82.56 & 0.19 & 0.96 \\
\hline Pelangi & 85.25 & 0.20 & 0.96 \\
\hline Terapi & 79.87 & 0.19 & 0.96 \\
\hline Sinau Kwansan & 82.22 & 0.19 & 0.97 \\
\hline
\end{tabular}

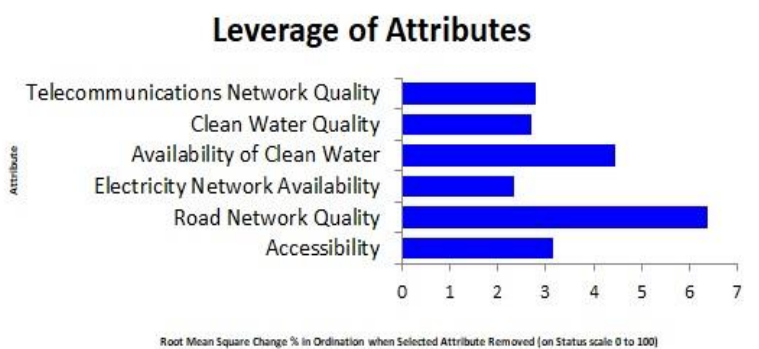

Figure 2 Leverage of economic attribute of Pelangi Kampong

The index in Pelangi Kampong (Table 2) is high. The status of the sustainability of the economic variable of Pelangi Kampong is categorized as highly sustainable. Based on the results of the leverage analysis, the attributes that influence the value of the sustainability index are the quality of the road network, and the availability of clean water (Figure 2).

\subsection{Environment variable}

The economic sustainability index of Bibit Kampong was the highest among the four kampongs. The score of Bibit Kampong was 52.68; it is followed by Terapi, Pelangi, and Sinau Kwansan (Table 4). Based on the sustainability status category (Table 2), Bibit Kampong and Pelangi Kampong are categorized as sustainable. At the same time, the other two are less sustainable, although the gap between Bibit Kampong and Sinau Kwansan Kampong was not deep (less than 10).

Table 4 Environment sustainability variables

\begin{tabular}{|l|c|l|l|}
\hline \multicolumn{1}{|c|}{ Kampong } & $\begin{array}{c}\text { Sustainability } \\
\text { index }\end{array}$ & Stress & $\mathbf{r}^{\mathbf{2}}$ \\
\hline Bibit & 52.68 & 0.20 & 0.95 \\
\hline Pelangi & 45.77 & 0.21 & 0.95 \\
\hline Terapi & 52.29 & 0.19 & 0.94 \\
\hline Sinau Kwansan & 43.83 & 0.19 & 0.95 \\
\hline
\end{tabular}

Interestingly, the environmental sustainability of Bibit Kampong was the highest, while its building density was the highest (114.7 building/Ha). The density of Bibit and Terapi Kampung were categorized high, while the other two were medium. The performance of other sub-variables was relatively no big difference. In terms of domestic waste disposal management, Terapi and Pelangi Kampong were slightly better. Terapi Kampong managed the recycling process of their domestic waste. Bibit Kampong was better in terms of green space provision since it has a greenhouse for growing plants, and each household managed to grow plants in pots.

Attributes that leverage the performance of environmental dimensions were the recycling process of domestic waste and drainage infrastructures (Figure 3). Bibit Kampong 
does not have a domestic waste recycling process, but it has good drainage channels.

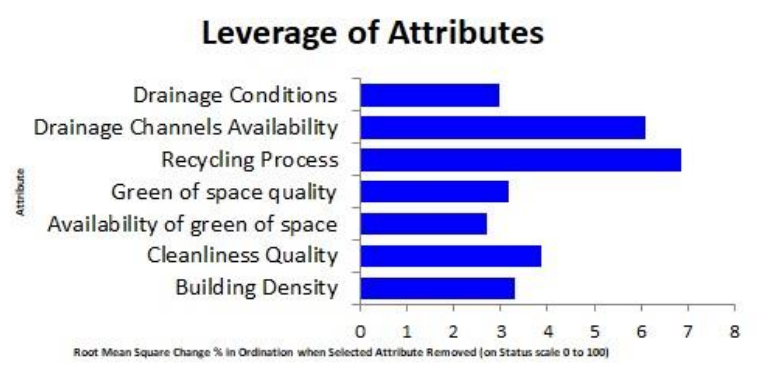

Figure 3 Leverage environment attribute of Bibit Kampong

\subsection{Social Variable}

Seven sub-variables of the social variable were measured by the MDS method. This time Sinau Kwansan showed the highest index, 79.63 (Table 5). All four kampongs were at very sustainable criteria. Based on stress value (0.19-0.20) and $r^{2}$ value (0.93-0.94), the number of attributes was adequate.

Table 5 Social sustainability variables

\begin{tabular}{|l|c|c|c|}
\hline \multicolumn{1}{|c|}{ Kampong } & $\begin{array}{c}\text { Sustainability } \\
\text { index }\end{array}$ & Stress & r2 \\
\hline Bibit & 75.09 & 0.20 & 0.93 \\
\hline Pelangi & 78.62 & 0.19 & 0.94 \\
\hline Terapi & 75.38 & 0.19 & 0.93 \\
\hline Sinau Kwansan & 79.63 & 0.20 & 0.94 \\
\hline
\end{tabular}

In terms of security facilities, all kampongs have security posts. Pelangi Kampong has a road portal as an additional security device. Three kampongs, Pelangi, Terapi, and Sinau Kwansan, have typical health facilities, namely posyandu (integrated health service posts), a facility to facilitate health check of babies, and under-five children. This facility is in a radius $500 \mathrm{~m}$. Other accessible health services are physicians, clinics, puskesmas (community health center), and hospitals.

Social activities within the four kampongs show a similar pattern. Pelangi kampong has balai RW (community hall) for social events, and Terapi Kampong has communal open space. Others use space on the street. Community empowerment was conducted concerning composting, greening, and plant nursery.

The leverage of social attributes of Sinau Kwansan Kampong is mostly influenced by the quality of health facilities, community participation, and security level (Figure 4).

\section{Leverage of Attributes}

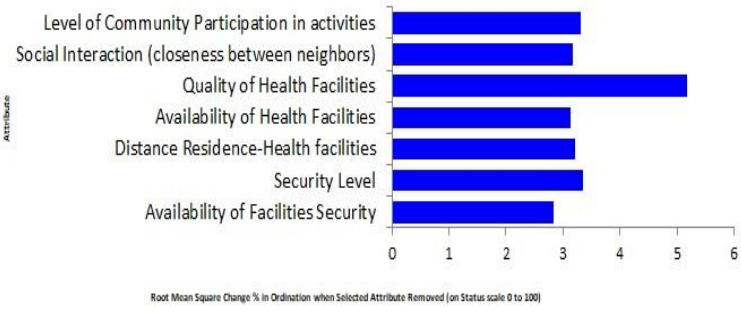

Figure 4 Leverage social attribute of Sinau Kwansan Kampong

\subsection{Education Variable}

Attributes for education are the condition of education facilities, home-school distance, community participation, accessibility, and education facilities provision. All four kampongs showed good performance; their performance on average was better than the other three variables. The best was Terapi Kampong (80.95), while the 'worst' was Bibit Kampong (72.08). Sinau Kwansan Kampong that was designed as the 'learning kampong', surprisingly got third rank (72.27) (Table 6).

Table 6 Education Sustainability Variables

\begin{tabular}{|l|c|c|c|}
\hline \multicolumn{1}{|c|}{ Kampong } & $\begin{array}{c}\text { Sustainability } \\
\text { index }\end{array}$ & Stress & $\mathbf{r}^{\mathbf{2}}$ \\
\hline Bibit & 72,08 & 0,23 & 0,92 \\
\hline Pelangi & 74,22 & 0,22 & 0,93 \\
\hline Terapi & 80,95 & 0,24 & 0,95 \\
\hline Sinau Kwansan & 72,27 & 0,22 & 0,93 \\
\hline
\end{tabular}

\section{Leverage of Attributes}

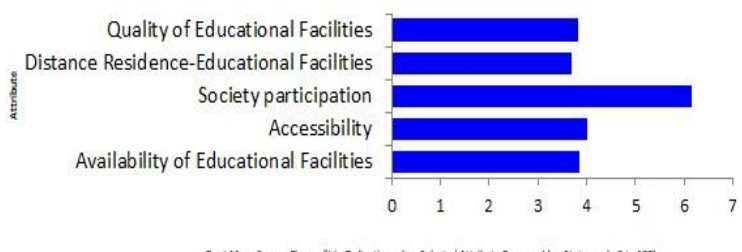

Figure 5 Leverage of educational attribute of Terapi Kampong

Each kampung at least has an education facility. Bibit Kampong has kindergarten school, Pelangi Kampong has three facilities: playgroup, kindergarten and primary school, Terapi Kampong has a kindergarten school, and Sinau Kwansan Kampong has playgroup, kindergarten and primary school. Those facilities are operated by private institutions except the primary school in Pelangi Kampong (public school). There are also one state primary school in an area adjacent to Terapi Kampong and another state primary school next to Sinau Kwansan Kampong. 
Education-related empowerment activities are mostly conducted in Pelangi Kampong (4 types of activities). The other three kampongs have one or two activities for each kampong.

Attributes that influenced the performance of Terapi Kampong were community participation (Figure 5). Other attributes were education facility quality (for Sinau Kwansan, Pelangi Kampongs), home-school distance (Bibit Kampong).

\subsection{Kampong in Comparison}

All 'development themes' for thematic kampongs were intended to improve the household's economy. The themes were designed to create kampong's branding by promoting unique activity within kampong. Bibit Kampong promotes plant nursery to boost the economy of the community; Pelangi Kampong promotes its social diversity; Terapi was developed in relation to environment theme; and Sinau means learning, therefore Sinau Kwansan is associated with an education theme.

The themes do not exactly correlate to the results of sustainability indices. Bibit Kampong's theme was the economy, while the result of the sustainability index was the best in the environment variable. The other three kampong's themes do not also match with the result of sustainability indices. The good news is that the four thematic kampongs in Malang have good performance, particularly in three variables: economy, social, and education. The lowest indices are still in the environmental dimension. It is understandable since kampongs were informally developed by communities. These kampongs are certainly not slum areas based on their sustainability indices. The analysis also indicates that thematic kampong development for the case of Bibit, Pelangi, Terapi, and Sinau Kwansan are successful in fighting against slum in the city.

The indices resulted from MDS analysis do not have significant differences with the result of Monte Carlo analysis. The results of the Monte Carlo analysis show that the difference in value $<2$ indicates that errors in giving attribute scores are relatively small, variations in scoring due to differences in opinion are relatively small, the analysis process carried out repeatedly is stable, and errors entering missing data can be avoided (Table 7).

Table 7 Differences between MDS and Monte Carlo

\begin{tabular}{|l|c|c|c|c|}
\hline Kampongs & Economy & Environment & Social & Education \\
\hline Bibit & 1,76 & 0,05 & 0,05 & 1,28 \\
\hline Pelangi & 1,92 & 0,03 & 0,03 & 1,45 \\
\hline Terapi & 1,61 & 0,84 & 0,84 & 0,45 \\
\hline $\begin{array}{l}\text { Sinau } \\
\text { Kwansan }\end{array}$ & 1,60 & 0,12 & 0,12 & 1,03 \\
\hline
\end{tabular}

\section{CONCLUSION}

Thematic kampong program in Malang was designed to generate activities of the respected communities in improving the quality of their settlements. The condition of six physical aspects (sub-variables) of the economic dimension was considerably good since there was no serious problem found on those six aspects. The lowest condition was on environmental sub-variables. All infrastructures were available, but perhaps the qualities were not as good as those at formal regular housing estate development areas. The conditions of social and educational sub-variables were good. These kampungs had diverse social activities with educational facilities distributed in each kampong.

The level of sustainability of the four kampongs are as follows (Table 8). Bibit Kampong shows the best performance in the environment variable, with also the highest index on average. The second is Pelangi Kampong, which shows the best performance in the economic variable. The following kampongs are Terapi and Sinau Kwansan.

Table 8 Sustainability index of kampongs

\begin{tabular}{|l|c|c|c|c|c|}
\hline Kampongs & Average & Econ. & Environ. & Social & Edu. \\
\hline Bibit & 70.11 & 82.56 & 52.68 & 75.09 & 72,08 \\
\hline Pelangi & 69.88 & 85.25 & 45.77 & 78.62 & 74,22 \\
\hline Terapi & 69.18 & 79.87 & 52.29 & 75.38 & 80,95 \\
\hline $\begin{array}{l}\text { Sinau } \\
\text { Kwansan }\end{array}$ & 68.56 & 82.22 & 43.83 & 79.63 & 72,27 \\
\hline
\end{tabular}

\section{REFERENCES}

[1] Cities Alliance, "Cities without slums action plan," Cities without slums, 2016.

[2] Ministry of Public Works and Public Housing, "Tentang Program Kota tanpa Kumuh (KOTAKU)," Cipta Karya General Directorate, 2019. [Online]. Available: http://kotaku.pu.go.id/. [Accessed: 15-Sep2019].

[3] . Surjono, A. Sudikno, and M. Ridhoni, "Lessons learnt from and sustainability assessment of Indonesian urban kampong," in IOP Conference Series: Earth and Environmental Science, 2017, vol. 70, no. 1, pp. 1-7.

[4] I. A. W. Hutama and D. Kristiadi, "Spatial Reconfiguration Initiatives for Informal-like Settlement Revitalization: A Case of Yogyakarta Urban Kampong” Plano Madani, 2019.

[5] B. Sudarwanto, G. Hardiman, A. Suprapti, and A. B. Sarjono, "The uniqueness and complexity of kampung city Bustaman Semarang Indonesia," in IOP Conference Series: Earth and Environmental Science, 2018. 
[6] A. Rifai, N. Asterina, and R. Hidayani, "The Theory and Practice: A Study of Creative Kampong in Solo. A Preliminary Study," in The 8th Rural Research and Planning Group International Conference: Innovations of Rural Development for Implementing Sustainable Decelopment Goals Development, 2017, pp. 568-585.

[7] T. Akbar and F. Alfian, "Kampung Tematik Sebagai Bentuk Partisipasi Masyarakat Dalam Permasalahan Permukiman Kumuh di Kota Malang” Wahana, vol. 7, no. 2 (2018) pp. 37-48.

[8] P. K. Wulandari, "Inovasi Pemuda Dalam Mendukung Ketahanan Ekonomi Keluarga (Studi Kasus Pada Kampung Warna-Warni Kelurahan Jodipan, Kecamatan Blimbing, Kota Malang),” J. Ketahanan Nas. (2017).

[9] O. Golubchikov and a Badyina, Sustainable housing for sustainable cities: a policy framework for developing countries. 2012.

[10] A. D. Basiago, "Economic, social, and environmental sustainability in development theory and urban planning practice," Environmentalist (1998).

[11] F. I. Ibrahim, D. Omar, and N. H. N. Mohamad, "Theoretical Review on Sustainable City Indicators in Malaysia,” Procedia - Soc. Behav. Sci. (2015).

[12] BPS, Indikator Perumahan dan Kesehatan Lingkungan. Jakarta: BPS, 2018.

[13] UN-Habitat, "Informal Settlements," 2015.

[14] Science for Environment Policy, "Indicators for sustainable cities," Eur. Comm., 2015.

[15] A. Chaidir and T. W. Murtini, "Keberlanjutan Permukiman Rawa Desa Baru di Kabupaten Hulu Sungai Utara Kalimantan Selatan,” J. Pembang. Wil. KOTA (2014).

[16] P. Kavanagh and T. J. Pitcher, "Implementing Microsoft Excel Software For Rapfish: A Technique for The Rapid Appraisal of Fisheries Status," Fish. Cent. Res. Reports (2004). 